\title{
Akira Kurosawa's Hakuchi (The Idiot) as a Dialogue with Dostoevsky on Existence, Moral Beauty and Trauma
}

\author{
Stefano Aloe (Verona)
}

\begin{abstract}
Akira Kurosawa's Hakuchi ("The Idiot", 1951), based on F. Dostoevsky's eponymous novel, is one of the most complex and ambitious films of the Japanese master. Deeply impressed by Russian literature, and namely by the work of Dostoevsky, Kurosawa demonstrates a will to adapt not only the plot and themes from the novel but also some particular features of its narrative construction. At the same time, the film is conceived as a free rewriting of the Russian source based on the Japanese cultural and historical framework of the traumatic post-war era. In doing that, Kurosawa made possible to develop Dostoevsky's reflections on the nature of Love and Evil according to philosophical categories of the Japanese culture - in particular by approaching the questions posed by the Russian writer under a non-Christian, but rather Zen-Buddhist point of view.
\end{abstract}

\section{Key words}

Akira Kurosawa; Fyodor Dostoevsky; The Idiot; Japanese Cinema; Post-war Trauma; Goodness and Evil

\section{Абстракт \\ К/ф А. Куросавы “Хакути» («Идиот») как диалог с Достоевским на теме существования, моральной красоты и травмы}

Фильм японского мастера кино Акиры Куросавы “Хакути» («Идиот», 1951), основанный на одноименном романе Ф.М. Достоевского, является одним из самых сложных и амбициозных шедевров режиссера. Под сильными впечатлениями от русской литературы, и в частности от творчества Достоевского, Куросава проявляет желание адаптировать не только сюжет и темы романа, но и некоторые специфические черты его повествовательной структуры. В то же время русский источник подвергается в фильме коренным изменениям в соответствии с травматическим историко-культурным контекстом послевоенной Японии. Таким способом, Куросава смог свободно развивать размышления Достоевского о природе любви и зла, опираясь на философские категории японской культуры, а в частности с не-христианским, а скорее дзен-буддистским подходом к вопросам, поставленным русским писателем.

\section{Ключевые слова}

Акира Куросава; Ф. М. Достоевский; «Идиот»; Японское кино; Послевоенная травма; Добро и Зло

The present paper is based on a speech given at the University of Tokyo during the International Dostoevsky Workshop "Dostoevsky as Culture and Representation" (February 16th, 2019). 
I would like to clarify that I am not a film critic. So, my notes do not aim at adding anything to the poetics of such a master as Akira Kurosawa (1910-1998). Conversely, it is useful to try to approach some levels of films from the perspectives of comparative literatures and history of literature, two fields I have an expertise in. That is the reason why I am going to analyse one of Kurosawa's masterpieces, Hakuchi (白痴, screenplay by Akira Kurosawa and Eijirō Hisaita), in which a peculiar dialogue with the inspiring Dostoevskij's novel The Idiot is active.

Hakuchi was shot in 1951. At that time, Kurosawa had just become one of the most famous directors in the world, after the international triumph of his Rashōmon (1950). Hakuchi is a difficult, mostly experimental film - both regarding to the work of the camera and the director's narrative choices. I am convinced that here Kurosawa wanted to adapt not only the plot and themes from Dostoevsky's novel but also some particular features of its narrative construction, as, for example, by adopting mostly a subjective angle that varies according to the points of view of the different characters.

A key example of Kurosawa's subjectivising technique can be seen in the scene showing the embarrassing arrival of Taeko Nasu (that's the name of Nastasya Filippovna in the film ${ }^{1}$ ) at Kayama's (ie. Ganya Ivolgin's) house: here the Japanese director adopts narrative paths that are analogous to Dostoevsky's - a theatrical intersection of the many characters involved, created by the continuous, dynamic change of perspective of the narrator (the camera in the film can be seen as a metaphor of him). The narration is played by turning the focus from one character to another using tight close-up cuts. Furthermore, the role of a "choral" collective is played by a very crowded room, which emphasizes the growth of shared emotional anxiety, up to the scandalous climax consisting in Kayama's vile smacking the Idiot's face. In this way, the audience, experiencing itself immersed in the rough moment and changing its perception by following the "indiscreet" movements of the camera, is fully involved in an atmosphere of general discomfort, which it shares with the characters in action. ${ }^{2}$ Moreover, an in-depth psychological study of the characters is typical in other films by Kurosawa of the same period; that allows to think that, despite its peculiar experimentalism, Hakuchi must be regarded strictly within the context of Kurosawa's whole production of the ' $40 \mathrm{~s}$ and ' $50 \mathrm{~s}$.

The reception of Hakuchi in Japan, as well as all over the world, was lukewarm, especially in comparison to the outstanding success of the recently rewarded Rashōmon: by the way, one of the possible reasons has to be found in the evident differences between the two films for what concerns style and setting. This unexpected changes of perspectives from the exotic Old Japanese tale in Rashōmon to a seemingly dark "neorealism" of Hakuchi disorientated public and critics. The production's cuts also contributed to

1 We can trace here one of the relevant characteristics of Kurosawa's "translation" of the plot from the Russian novel to the Japanese film: according to a new contextualisation of the plot, all the characters' names are changed into Japanese ones, as well as places, acts, reality and customs refer to Japan and Japanese life of the post-war period.

2 This kind of stylistic choices did not yet find approval by many film critics, cf. this recent review: "The visual style is hampered considerably by small sets in which too many actors are required to perform, often resulting in a stagey and stilted atmosphere" (NOLLEN, Scott Allen: Takashi Shimura: Chameleon of Japanese Cinema. Jefferson, NC: McFarland \& Co., 2019, p. 57. 
inhibit the reception of the film, whose running time was reduced in the studios by half from over four hours (265 minutes) to less than three (166 minutes). The cuts affected especially the first part of the film, compromising the logical development of the main characters' psychologies. First of all, became unclear the reasons which brought to idiocy the main hero became unclear: "After Rashomon I made a film of Dostoevsky's The Idiot (Hakuchi, 1951) for the Shochiku studios. This Idiot was ruinous. I clashed directly with the studio heads, and then when the reviews on the completed film came out, it was as if they were a mirror reflection of the studio's attitude toward me. Without exception, they were scathing,"3

An internal analysis of fundamental human questions, implicating the moral impossibility to keep oneself neutral in social life situations, involves all Kurosawa's main heroes similarly. Key examples are doctor Sanada in Drunken Angel (1948), doctor Fujisaki in The Quiet Duel (1949), Mr Watanabe in Ikiru (1952), and all the characters of Rashōmon, each of which depicts reality in a different manner and, in doing this, they radically distort the same perception of the burden of guilt and responsibilities.

As critics have often noticed, ${ }^{4}$ two factors motivate Kurosawa's philosophical research of those years: the war trauma, and, only partially connected to it, the epochal crisis of the Japanese traditional way of life.

The tragedy of WWII does not only imply the immense wave of destruction and human casualties, and for nations like Japan, Germany and Italy not only in a matter of total military and political defeat, but also - and first of all - in the trauma of the collective guilt generated by the awareness of Evil's pervasive action, of its almost unlimited potential. It could be hardly by chance that the importance of Dostoevsky significantly grew up in the post-war philosophy and literature all over the world: the Russian novelist was recognised as a prophet of the tremendous consequences of totalitarian utopianism, as no one had ever described the nature of Evil so vividly and at the same time without separating it from the nature of man himself. ${ }^{5}$ In Dostoevsky's work, Good and Evil are part of a whole, conflicting but paradoxically complementary entities inside every

3 KUROSAWA, Akira: Something like an autobiography. New York: Randon House, 1983, pp. 186-187. Despite of all this, Kurosawa always considered Hakuchi as his masterpiece, cf. KLINOWSKI, Jacek GARBICZ, Adam: Feature Cinema in the 20th Century: Volume Two: 1951-1963: a Comprehensive Guide. London: Planet RGB Limited, 2012.

4 See BURRY, Alexander: Transposing the Apocalypse: Kurosawa's The Idiot. Canadian Review of Comparative Literature. Vol 34, No 2 (2007), pp. 172-188 (eventually re-elaborated as a chapter of the author's monography Multi-Mediated Dostoevsky: Transposing Novels Into Opera, Film, and Drama. Evanston (IL): Northwestern University Press, 2011, pp. 107-138).

5 About Dostoevsky's place in the world philosophy and culture of the post-war period, see among others: GIVONE, Sergio: Dostoevskij e la filosofia. Bari: Laterza, 2007 (2 ed.); SCHULT, Maike: Im Banne des Poeten: Die theologische Dostoevskij-Rezeption und ihr Literaturverständnis. Göttingen: Vandenhoeck \& Ruprecht, 2012; ALOE, Stefano (ed.): Su Fëdor Dostoevskij. Visione filosofica e sguardo di scrittore. Napoli: La scuola di Pitagora, 2012. More specifically about the reception of Dostoevsky in Japan, see KINOSHITA, Toyofusa: Dostoevskij i japonskaja literatura. In: KINOSHITA, Toyofusa: Antropologija i poètika tvorčestva F. M. Dostoevskogo. Sankt-Peterburg: Serebrjanyj Vek, 2005, pp. 133-201; KINOSHITA, Toyofusa: Vosprijatie i izučenie tvorčestva Dostoevskogo v Japonii za poslednie 40 let v svete istorii vosprijatija tvorčestva pisatelja s konca XIX v. In: Dostoevskij. Materialy i issledovanija. Tom 20. Sankt-Peterburg: Nestor-Istorija, 2013, pp. 194-219. On Japanese reception of Dostoevsky's novel The Idiot, see SAISU, Naohito: Vosprijatie romana „Idiot" v Japonii. Filosofskij polilog. Vyp. 1, 2017, pp. 79-88. 
individual. Dostoevsky does not seem to be interested in the Being, but he is rather concentrated on the Existing, i.e. on the real experience of the grief of life. Is it possible to be good ("totally good") like the Idiot? Or isn't goodness a question of Being, an innate mark? Doesn't it need, like other qualities of the mankind, to generate in the experience of life? The downfall of Prince Myshkin might indicate this second option: the ideal of natural goodness cannot stand the test of the Existence, and the abstract purity of being converts into foolishness and tragedy. Actually, foolishness and tragedy cannot be attributes of the Being, as they originate from the Existence, from conflicts and sorrow of the changing reality. Existence is the collision between Essence and Time. That is the drama of the conversion of the Being into the Existent. Here the downfall from purity might be the only way to recover a human, sorrowful, active and newly purified goodness. ${ }^{6}$

This reflection on the sorrowful "purification of the Goodness" by its conversion from the category of Being to the category of Existence can be identified as a crucial issue in Kurosawa's film. Incidentally, novel writing to Dostoevsky as well as film making to Kurosawa is the occasion to convert ideas into life: both a novel and a film needing a kinetic development of facts and situations, a forward motion which makes possible to bring into existence what has been an abstract concept or a hypothesis.

It is hard to say whether Kurosawa intended his Idiot, Kinji Kameda, as a metaphor of the Japanese traumatized post-war society - "purified" by the disease of the national defeat but converted for the same reason in an organism deprived of memory and roots. The character of Kameda is weak, passive, and thus incapable of playing the role of the "pure" and the "good" one in a positive way, and is eventually condemned to the irrelevant role of the "fool angel" in the tragedy of Taeko Nasu. ${ }^{7}$ At the same time, Kameda's naivety seems to play an unintentional upsetting role in the stiff and conventional Japanese society, shattering all the rules of good manners in the same way Kameda breaks a precious vase into pieces at Mr Tohata's (i.e. Totsky's) house. That is maybe the exact reason why the feeble figure of Kameda, with his lack of passion, allows Kurosawa to better highlight the personalities of the other characters in the film (in particular Taeko Nasu and Denkichi Akama, respectively Nastasya Filippovna and Parfyon Rogozhin), making them very vivid in their intricate mix of passions, virtues, vices and heroism.

6 For a comparison between Dostoevsky's philosophical assessments and I. Kant's - in many respects opposite - moral philosophy, see E. Cherkasova: "Dealing with a person as a whole, even if this "whole" strives toward disintegration and contradiction, is one of the key features of Dostoevsky's ethics. In this, he differs radically from Kant, who meticulously separates the morally significant constituents of human nature - good will, practical reason, conscience, and the feeling of respect for the moral law - from allegedly natural or unethical ones anything passionate, emotional, or bodily" (CHERKASOVA, Evgenia: Dostoevsky and Kant: Dialogues on Ethics. Amsterdam - New York: Rodopi, 2009, p. 45).

7 It is worth to mention Alexander Burry's interpretation of this film as a post-apocalyptic one. Kurosawa, argues Burry, "turns an apocalyptic novel into a post-apocalyptic film. In Bakhtinian terms, he transforms Dostoevsky's chronotope, with its dynamic, frenzied depiction of onrushing catastrophe, into a frozen, static temporal and spatial representation of an exhausted postwar Japan [...] In Kurosawa's film, snow in effect acts as a totalizing instrument of death, or a post-apocalyptic grave, perhaps even symbolic of the atomic residue literally burying Hiroshima, Nagasaki, and their inhabitants. This symbolism is further reinforced by the traditional Eastern associations of snow (and whiteness in general) with death, burial, and mourning" (BURRY, Alexander: Transposing the Apocalypse: Kurosawa's The Idiot, cit., pp. 172; 182). 
Unlike Dostoevsky's hero, Kurosawa's Hakuchi seems to be neither a figure of Christ, nor a Japanese Don Quixote. Probably his intertextual references should be searched within Japanese spirituality and culture, for instance in Zen Buddhism. Since I am not qualified for such a survey into Japanese culture, I just notice that the well-known presence of many references to Russian literature in Kurosawa's oeuvre is connected first of all to the themes and figures of righteousness and guilty conscience. I believe that Kurosawa was deeply moved by Prince Myshkin's supernatural goodness and naive openness, probably because of the paradoxical worthlessness and impotence of this strange kind of beauty. Kameda, even more than Myshkin, expresses the impossibility for a "perfect moral beauty" to settle down in a corrupted and brutalized reality. Here we can find a basic difference between the Dostoevskian prototype and Kurosawa's interpretation of it: while Myshkin is a person without a conscious past who came to social life, culture, and history only in his adult age, Kameda is a man who fell into epilepsy and mental trauma because of the war. Kameda's past was lost in captivity together with sanity and social mechanisms. So, his moral beauty is the strange consequence of a deep shock and not of something innate. In Hakuchi, Kurosawa sacrifices the Dostoevskian character of the ill boy Ippolit, but not the motif of conscious experience of death (and of illness). Kinji Kameda was sentenced to death during his imprisonment and then got a pardon just in front of the firing squad. The experience of death is what converts him into an idiot. Only a specialist could introducte us into what is the status of an idiot in Japanese tradition, and I wonder if it is possible to make parallels with the Russian concept of "yurodstvo". ${ }^{8}$ Worth to be noticed is that the word "hakuchi", traditionally used to translate the title of Dostoevsky's novel The Idiot, sounds rare and a bit archaic in contemporary Japanese language, as well as the two-kanji-ideograms combination that indicates this word. ${ }^{9}$

Nevertheless, the post-war candid behaviour of Kameda is more a request for help than the moral aid the others could expect from him. Purity does not help souls after the disasters of the war - it is unarmed. In other Kurosawa's contemporary films, we can find the same quest formulated from the opposite point of view: impure and ashamed heroes, involved into sin and fault by life itself, can be stimulated to react positively and devote themselves entirely to a strong moral aim, improving others' life, and redeeming their own honour. This pattern is detectable in both main protagonists of Drunken Angel - Doctor Sanada and bandit Matsunaga - and Mr Watanabe in Ikiru. It is also the case of doctor Fujisaki in The Quiet Duel. Many of these heroes are sentenced to death by illness or by men: that is another important link between Kurosawa's poetics and the Idiot.

8 Anyway, no doubt that Russian "yurodstvo" draws keen attention of Japanese scholars and lovers of Russian culture, as testified by several studies. See for ex.: NAKAZAWA, Atsuo:Jurodstvo v „Žitii protopopa Avvakuma“. Japanese Slavic and East European Studies, Vol. 9, 1988, pp. 39-54; KOBAYASHI, Ginko: Religioznoe soznanie japoncev i Dostoevskij: popytka podchoda $k$ teme „Vosprijatie Dostoevskogo v Japonii“. In: KASATKINA, Tat'jana Aleksandrovna (ed.): Dostoevskij $i$ XX vek. V 2 tt.. Tom 2. T. 2. Moscow, IMLI RAN, 2007, pp. 440-455.

$9 \quad$ I express my gratitude to Prof. Ikuo Kameyama for this information. 
Another inspiring aspect in Hakuchi and other Kurosawa's films of the same period emerges by comparing them with the masterpieces of Italian Neorealism. Indeed, parallels are fascinating not only as far as the poetics of these films concerns, but also in the use of similar creative patterns strictly connected to the Russian literature: subjects from Russian classic authors undergo radical adaptation to other cultural, historical, and geographical contexts, though keeping alive the more profound philosophical significance of the inspiring original works. This occurs, for instance, in Alberto Lattuada's Overcoat (1952), adapted from Gogol's tale, in Luchino Visconti's White Nights (1957), inspired by Dostoevsky's tale, as well as in Kurosawa's Hakuchi and Ikiru, where the latter is inspired by Leo Tolstoy's Death of Ivan Il'ich. ${ }^{10}$

Parallels are strikingly evident: all these directors follow one of the typical conditions of classic Russian literature - the focus on contemporary life. Neither Kurosawa nor Lattuada and Antonioni are interested in filming exotic 19th century Russia - which has been the tendency of world cinema in the ' 30 s - they do not want to replicate the plots of their models mechanically; they strive to insert them into the flow of life of their own countries and era - i.e., destroyed countries in the first post-war years. Therefore, the Italian Neorealism, as well as Kurosawa's films appear deeply respectful to the inner meaning and modernity of Dostoevsky's, Tolstoy's, Gogol's works, despite the fact that they decontextualise them from their Russian matrix. ${ }^{11}$ What occurs is a revitalisation of the ethical and philosophical quests of Russian literary works, amplified in the concrete Italian and Japanese contexts. In Visconti's White Nights, the two heroes of the film meet among the ruins of bombed houses in a generically-labelled Italian town; Lattuada's Overcoat is shot in a recognisable foggy and poor Northern Italian town of Pavia; Kurosawa chooses a miserable and frozen Hokkaido as the background of his Idiot, adapting realism the plot of Dostoevsky's novel to a specifically Japanese entourage. In all these films, deep attention is given to all kind of everyday life details. The pursuit of truth, righteousness, social and individual justice, the necessity to reload the same mechanisms of life in search for new hopes: all this seems to be the fundamental meaning of Hakuchi and the abovementioned Italian films.

Only going through the specific experience of the national present, the subject of the Idiot could contribute to the self-reflexion of the wounded post-war society. Something

10 By the way, not only Dostoevsky's Idiot is in the artistic horizon of the Japanese director: Kurosawa seemingly has in mind a tale by Nikolay Gogol, The Portrait, when writing the screenplay (together with Ryūzō Kikushima) of his film Stray Dog, ("Nora Inu", 1949), centred on the theme of the complicated grief and of the consequent redemption. In Stray Dog someone commits a crime using the gun detective Murakami has stolen; Murakami must retrieve it as to save his honour and good conscience. A situation very close to that is in Gogol's tale, where a very religious painter Chartkov makes a portrait which acquires the is demonic features of the man who has commissioned it; as the painter acknowledges what has occurred, he spends his life in redeeming his unintentional fault and seeking the portrait as to destroy it. A Chekhovian motif can be seen in Drunken Angel as well.

11 Cf. De LOTTO, Cinzia: Ved'my, šineli i revizory v ital'janskom kino. Novoe literaturnoe obozrenie, No. 61, 2003, pp. 179-203; LEKMANOV, Oleg: Motiv snega v fil'mach A. Kurosavy "Idiot" $i$ L. Viskonti "Belye noči". In: VOLGIN, Igor' Leonidovič (ed.): IV Meždunarodnyj simpozium "Russkaja slovesnost' v mirovom kul'turnom kontekste”. Izbrannye doklady i tezisy. Moscow: Fond Dostoevskogo, 2012-2014, pp. 489491. 
is awe-inspiring and difficult for a non-Japanese viewer of Hakuchi: the perception that most of the code of conduct of the characters cannot be understood without an in-depth knowledge of the Japanese culture. Such kind of difficulties in reception can be exemplified by quoting what probably is the most impressive scene of the film.

I refer to the sequence in the epilogue, in which Kinji Kameda and Denkichi Akama enter Akama's house, where Taeko's body lies in darkness. The conclusion of the film seems to transfer the plan from the level of reality to a level of cathartic tragedy, where the foolishness of the two heroes is transformation into a kind of ritual masks expresses the foolishness shaped by amazing light and darkness effects. Kurosawa himself explained his conception of drama as a synthesis of European musical genre of symphony and the structure of the traditional Japanese Noh theatre: "A good structure is that of the symphony, with its three or four movements and differing tempos. Or one can use the Noh play with its three-part structure: jo (introduction), ha (destruction) and kyu (haste). If you devote yourself fully to Noh and gain something good from this, it will emerge naturally in your films. The Noh is a truly unique form that exists nowhere else in the world. I think the Kabuki, which imitates it, is a sterile flower." 12

The influence of Noh theatre on Kurosawa's work is crucial not only for the structure of the plot, but notably for what concerns the composition of the scene: many crowd scenes in Hakuchi, in their precious symmetry, are very close to tableau vivants and reflect, indeed, the poetics of Noh. As noticed in a smart paper by Xiaoxing Wang: "Personality of a Noh actor vanishes completely being swallowed by the character of the mask and that is how the actor finds his own true nature. In case of Kurosawa's film the audience following the actors' play, which is conceived of as embodying the mask, is able to embrace the very depth of feeling and experience. Kurosawa, along with Dostoevsky's concept, emphasizes suffering as the most significant reality displayed in "The Idiot". Catharsis, comprehension of the deep human essence, become possible through complete integration and dissolution [...].Faces appearing in close-ups cause an association with living Noh masks which clearly manifest what characters deeply feel [...]. The Japanese and the European concepts and understandings of the mask have fundamental distinctions. Japanese culture empowers the mask not to conceal but to disclose and express the character played by the actor and to concentrate aesthetic culmination of human passions in a symbolic form." 13

Here Kurosawa's genius is most of all rooted in a Japanese conception of drama. There is no other way out this tragic situation but a dive into a deeper level of reality, where the emotional forces at play become mythological and archetypical. That was a perfect solution for a film that is true to Dostoevsky's pattern and definitely original at the same time.

12 KUROSAWA, Akira: Something like an autobiography. New York: Randon House, 1983, p. 193.

13 WANG, Xiaoxing: Interpretations of Fyodor Dostoevsky's "The Idiot" by Akira Kurosawa and Andrzej Wajda: A comparative analysis. Vestnik of Saint Petersburg University. Asian and African Studies, 2018, vol. 10, issue 2 , pp. $166 ; 168$. 


\section{Literature}

ALOE, Stefano (ed.): Su Fëdor Dostoevskij. Visione filosofica e sguardo di scrittore. Napoli: La scuola di Pitagora, 2012.

BURRY, Alexander: Transposing the Apocalypse: Kurosawa's The Idiot. Canadian Review of Comparative Literature. Vol 34, No 2 (2007), pp. 172-188 (see also a slightly reelaborated version: Secularizing Dostoevsky's "Positively Good Man": Kurosawa's The Idiot. In: BURRY, Alexander: Multi-Mediated Dostoevsky: Transposing Novels Into Opera, Film, and Drama. Evanston, IL: Northwestern University Press, 2011, pp. 107-138).

CHERKASOVA, Evgenia: Dostoevsky and Kant: Dialogues on Ethics. Amsterdam - New York: Rodopi, 2009.

De LOTTO, Cinzia: Ved'my, šineli i revizory v ital'janskom kino. Novoe literaturnoe obozrenie 61, 2003, pp. 179-203.

GIVONE, Sergio: Dostoevskij e la filosofia. $2^{\circ}$ ed. Bari: Laterza, 2007.

KINOSHITA, Toyofusa: Dostoevskij i japonskaja literatura. In: KINOSHITA, Toyofusa: Antropologija i poètika tvorčestva F. M. Dostoevskogo. Sankt-Peterburg: Serebrjanyj Vek, 2005, pp. 133-201.

KINOSHITA, Toyofusa: Vosprijatie i izučenie tvorčstva Dostoevskogo v Japonii za poslednie 40 let v svete istorii vosprijatija tvorčestva pisatelja s konca XIX v. In: Dostoevskij. Materialy i issledovanija. Tom 20. Sankt-Peterburg: Nestor-Istorija, 2013, pp. 194-219.

KLINOWSKI, Jacek - GARBICZ, Adam: Feature Cinema in the 20th Century: Volume Two: 19511963: a Comprehensive Guide. London: Planet RGB Limited, 2012.

KOBAYASHI, Ginko: Religioznoe soznanie japoncev $i$ Dostoevskij: popytka podchoda $k$ teme „Vosprijatie Dostoevskogo v Japonii“. In: KASATKINA, Tat'jana Aleksandrovna (ed.): Dostoevskij i XX vek. V 2 tt.. Tom 2. T. 2. Moscow: IMLI RAN, 2007, pp. 440-455.

KUROSAWA, Akira: Something like an autobiography. New York: Randon House, 1983.

LEKMANOV, Oleg: Motiv snega v fil'mach A. Kurosavy "Idiot" $i$ L. Viskonti "Belye noči". In: VOLGIN, Igor' Leonidovič (ed.): IV Meždunarodnyj simpozium "Russkaja slovesnost' v mirovom kul'turnom kontekste”. Izbrannye doklady i tezisy. Moscow: Fond Dostoevskogo, 2012-2014, pp. 489-491.

NAKAZAWA, Atsuo: Jurodstvo v „Žitii protopopa Avvakuma“. Japanese Slavic and East European Studies 9, 1988, pp. 39-54.

NOLLEN, Scott Allen: Takashi Shimura: Chameleon of Japanese Cinema. Jefferson, NC: McFarland \& Co., 2019.

SAISU, Naohito: Vosprijatie romana „Idiot“ v Japonii. Filosofskij polilog 1. 2017, pp. 79-88.

SCHULT, Maike: Im Banne des Poeten: Die theologische Dostoevskij-Rezeption und ihr Literaturverständnis. Göttingen: Vandenhoeck \& Ruprecht, 2012.

WANG, Xiaoxing: Interpretations of Fyodor Dostoevsky's “The Idiot” by Akira Kurosawa and Andrzej Wajda: A comparative analysis. Vestnik of Saint Petersburg University. Asian and African Studies, vol. 10, issue 2, pp. 159-175. 


\section{prof. PhDr. Stefano Aloe}

Dipartimento di Lingue e Letterature Straniere

Università di Verona

L.ge P.ta Vittoria, 41, 37100 Verona, Italia

stefano.aloe@univr.it

Toto dílo lze užít v souladu s licenčními podmínkami Creative Commons BY-SA 4.0 International (https://creativecommons.org/licenses/by-sa/4.0/legalcode). Uvedené se nevztahuje na díla či prvky (např. obrazovou či fotografickou dokumentaci), které jsou v díle užity na základě smluvní licence nebo výjimky či omezení príslušných práv. 
